\title{
Sistem Pembayaran Mixed Method INA-CBGs dan Global Budget di Rumah Sakit: Tahap 1 Uji Coba Mixed Method INA- CBGs-Global Budget di Indonesia
}

\author{
Health Service Payment System in Hospital \\ Mixed INA-CBGs and Global Budget
}

\author{
Fachmi Idris $^{1}$, Atik Nurwahyuni ${ }^{2}$, Mundiharno ${ }^{1}$, Benjamin Saut ${ }^{1}$, Citra Jaya ${ }^{1}$, Wan Aisyiah Baros ${ }^{1}$, \\ Ayunda Oktavia ${ }^{1}$, Dedy Revelino ${ }^{1}$, Erzan Dhanalvin ${ }^{1}$, Rasinta Ria Ginting ${ }^{1}$ \\ ${ }^{1}$ BPJS Kesehatan \\ ${ }^{2}$ Departemen Administrasi dan Kebijakan Kesehatan, Fakultas Kesehatan Masyarakat, Universitas Indonesia \\ Korespondensi: Wan Aisyiah Baros \\ E-mail: wan.aisyiah@bpjs-kesehatan.go.id
}

\begin{abstract}
Abstrak
Tidak ada sistem pembayaran pelayanan kesehatan yang sempurna dalam penerapannya termasuk sistem pembayaran DRG (Diagnosis-Related Groups) yang lebih dikenal dengan nama INA-CBGs (Indonesia Case-Based Groups) di Indonesia. Beberapa negara yang mengadopsi DRG telah menerapkan kebijakan pembayaran mixed method DRG-Global Budget dengan variasi implementasinya demi menjaga kesinambungan sistem jaminan kesehatan nasional di negaranya. BPJS Kesehatan menginisiasi studi operasional penerapan sistem pembayaran rumah sakit mixed-method INA-CBGs dan Global Budget mulai tahun 2018. Terdapat tiga tahapan dalam uji coba sistem pembayaran rumah sakit mixed-method INA-CBGs dan Global Budget ini. Tahap pertama adalah Global Budget Tanpa Resiko yang bertujuan untuk menguji metode penghitungan global budget dan mengidentifikasi tantangan yang dihadapi bila kebijakan mixed method INA-CBGs dan Global Budget ini diberlakukan. Studi dilakukan di 5 (lima) kabupaten/kota di 30 rumah sakit (RS). Hasil studi menunjukkan bahwa metodologi penghitungan global budget yang diterapkan cukup akurat untuk memprediksi realisasi klaim di RS. Penghitungan global budget di tingkat kabupaten/kota lebih akurat hasilnya dibandingkan dengan menghitung global budget di tingkat RS karena mengakomodir shifting pasien dari RS yang satu ke RS yang lainnya akibat perubahan kapasitas RS. Perubahan kapasitas RS di tahun berjalan dan adanya pandemi COVID-19 menyebabkan adanya selisih antara penghitungan global budget dan realisasi klaim.

Kata kunci: Sistem Pembayaran, INA-CBGs, Global Budget
\end{abstract}

\begin{abstract}
When it comes to provider payment system, no one shoe fits all including DRG payment system which in Indonesia are known as INA-CBGs. In some countries that used DRG have mixed it with Global Budget in various mechanisms to maintain the sustainability of the national health insurance system in their countries. BPJS Kesehatan initiated a three-stage pilot study on the implementation of the mixed-method hospital payment system INA-CBGs and Global Budget starting in 2018. The first stage is the Non-Risk stage which aims to test the accuracy of the global budget calculation and prediction and to identify the challenges faced when the mixed-method payment is implemented. The pilot was conducted in 5 districts in 30 hospitals. Initial results show that the calculation and prediction method is accurate to predict the actual hospital claims in the following year. The calculation of the global budget at the district level is more accurate than the hospital level because it accommodates patient transfer from one hospital to another due to changes in hospital capacity. Changes in hospital capacity in the current year and the COVID-19 pandemic requires some adjustments to the budget calculation.
\end{abstract}

Keywords: Provider Payment System, INA-CBGs, Global Budget 


\section{Pendahuluan}

Pembayaran fasilitas kesehatan dapat diartikan secara sempit sebagai mekanisme pemberian dana kepada fasilitas kesehatan untuk mengganti biaya pelayanan yang telah dikeluarkannya. Namun pembayaran fasilitas kesehatan dapat pula diartikan sebagai suatu hal yang lebih luas di mana ia dan subsistem yang lain seperti kontrak, mekanisme akuntabilitas yang menyertai metode pembayaran, dan sistem informasi manajemen dan lain-lain bekerja bersama-sama untuk mencapai sebuah tujuan kebijakan. Hal ini dimungkinkan karena setiap metode pembayaran fasilitas kesehatan memunculkan insentif berupa sinyal-sinyal ekonomi yang akan direspon oleh fasilitas kesehatan untuk memaksimalkan keuntungannya. Pembuat Kebijakan dapat menentukan respon positif apa yang diharapkan akan muncul dari pemberlakuan sebuah metode pembayaran. Inilah yang membuat Sistem Pembayaran Fasilitas Kesehatan sering disebut sebagai tools yang sangat powerful untuk mencapai tujuan kebijakan (Langenbrunner, Cashin, \& O'Dougherty, 2009) (McIntyre \& Kutzin, 2016).

Secara umum tujuan implementasi Diagnosis Related Group (DRG) yang dikenal di Indonesia sebagai INA-CBGs bila digunakan sebagai mekanisme pembayaran ke rumah sakit adalah peningkatan efisiensi, transparansi, mengurangi lama hari rawat, peningkatan mutu layanan, memberikan ruang yang kondusif bagi persaingan rumah sakit, perencanaan, penganggaran serta peningkatan manajemen pelayanan Kesehatan (HOPE, 2006; Céu Mateus, 2009) (Francis, Mertens, Closon, \& Hofdijk, 2001). Namun dalam implementasinya, tidak ada metode pembayaran yang sempurna. Tidak jarang respon yang muncul adalah respon negatif yang seharusnya juga sudah diantisipasi oleh pembuat kebijakan dengan membuat aturanaturan yang menyertai kebijakan pembayaran tersebut (O’Dougherty, et al.,2009) (Cots, Chiarello, Salvador, Castells, \& Quentin, 2011).

Terdapat 3 strategi utama RS bila dibayar dengan mekanisme INA-CBGs yaitu efisien di setiap kasusnya, memaksimalkan tagihan di setiap klaimnya dan meningkatkan jumlah kasus. Strategi ini dapat ditempuh dengan cara yang positif namun tidak jarang RS menempuh dengan cara yang tidak diharapkan oleh pengambil kebijakan (unintended consequences) misalnya merujuk pasien yang dianggap kurang menguntungkan (dumping), memulangkan pasien lebih awal ketika masih membutuhkan perawatan (bloody/early discharge), meminta pasien untuk datang kembali berobat di rumah sakit (readmisi, supply induced demand), mengurangi layanan kesehatan, dan pemberian layanan tambahan (gaming) untuk mendapatkan grup dengan bayaran lebih tinggi serta mengganti kode untuk mendapatkan tarif yang lebih besar (up-coding) (Cots, Chiarello, Salvador, Castells, \& Quentin, 2011) (García, Gomez, Hidalgo, \& Fernandez, 2004).

Hampir semua negara yang mengadopsi DRG telah menerapkan kebijakan pembayaran mixed method DRG-Global Budget dengan variasi implementasinya demi menjaga kesinambungan sistem jaminan kesehatan nasional di negaranya (Mathauer, Inke and Wittenbecher; 2021 dan Busse et.al, 2011) (OECD, 2013) (Schreyogg, Stargardt, Tiemann, \& Busse, 2006). Global Budget bermanfaat untuk mengendalikan kecenderungan peningkatan aktifitas akibat pembayaran DRG dan juga untuk menjaga budget di tingkat nasional (Fattore \& Torbica, 2006). Global budget merupakan cara pendanaan RS untuk semua pelayanan/aktifitas selama 1 (satu) tahun sehingga dalam penghitungannya akan mempertimbangkan jumlah pelayanan pada tahun sebelumnya, 
kegiatan lain yang diperkirakan akan dilaksanakan, dan kinerja RS tersebut. Dengan global budget maka RS memiliki kepastian anggaran selama kurun waktu tertentu dan memiliki keleluasaan untuk memanfaatkan anggaran yang ada guna meningkatkan pelayanan kesehatan. Di sisi lain, badan penyelenggara memiliki kepastian biaya pelayanan di RS dan dapat fokus kepada peningkatan kualitas pelayanan peserta serta penguatan sistem jaminan kesehatan nasional. Pengalokasian dana ini harus dilakukan secara adil (fair) dan transparan kepada faskes, oleh karenanya luarannya harus jelas dan terukur. Kedua belah pihak (badan penyelenggara dan RS) harus mengetahui dengan pasti bahwa besaran budget yang telah ditetapkan adalah untuk memenuhi luaran yang telah disepakati (O’Dougherty, et al., 2009). Kebijakan ini juga sangat penting untuk diberlakukan di Indonesia namun penting pula untuk diadakannya uji coba guna melihat dampaknya baik dari sisi pelayanan kesehatan maupun dari pembiayaan.

BPJS Kesehatan menginisiasi studi operasional penerapan sistem pembayaran RS mixed-method INA-CBGs dan Global Budget. Terdapat 3 (tiga) tahapan dalam uji coba sistem pembayaran ini: tahap pertama adalah Global Budget Tanpa Resiko. Pada tahap ini BPJS Kesehatan bersama RS menghitung dan menyepakati besaran global budget namun belum ada penerapan risiko atas lebih atau kurangnya budget tersebut sehingga besaran dana yang akan diterima oleh RS sesuai dengan klaim yang diajukan oleh RS. Pada tahun pertama, budget yang telah disepakati belum diberikan kepada RS (virtual) dan proses pembayaran klaim tetap mengikuti prosedur yang berlaku sesuai sistem pembayaran INA- CBGs. Risiko lebih atau kurang atas budget yang dihitung ditanggung sepenuhnya oleh BPJS Kesehatan. Kinerja RS dipantau dan dihitung namun tidak berdampak pada besaran budget. Kinerja tersebut yang dipantau adalah readmisi, casemix, casemix index, Rujukan Horisontal, Pulang Atas Permintaan Sendiri dan infeksi nosokomial. Pada tahun kedua di tahap pertama, BPJS Kesehatan membayar budget RS per triwulan dengan penangguhan (withhold) diberikan pada akhir tahun tanpa adanya penerapan risiko kepada RS atas lebih atau kurangnya budget. Besaran withhold yang digunakan pada studi ini sebesar $30 \%$. Kinerja RS dihitung namun tidak berdampak pada besaran budget.

Tahap kedua adalah Global Budget Risiko Sebagian. Pada tahap ini budget yang telah disepakati sudah diberikan kepada RS per triwulan dan withhold diberikan pada akhir tahun dengan penerapan pembagian risiko pada kedua belah pihak atas lebih atau kurangnya budget. Persentase pembagian risiko ini akan disepakati besarannya dengan menyesuaikan kondisi keuangan masing-masing pihak dengan besaran persentase lebih besar pada BPJS Kesehatan. Proses pembayaran klaim tetap mengikuti prosedur yang berlaku dan menggunakan tarif INA-CBGs. Risiko lebih atau kurang atas budget dihitung dan dibagi kepada kedua pihak. Kinerja rumah sakit menjadi pertimbangan besaran budget tahun berikutnya.

Tahap ketiga adalah Global Budget Risiko Penuh. Pada tahap ini budget yang telah disepakati diberikan kepada RS per triwulan dan withhold diberikan pada akhir tahun. Pada tahap ini sudah ada penerapan risiko penuh kepada RS atas lebih atau kurangnya budget. Untuk proses pembayaran klaim tetap mengikuti prosedur yang berlaku dan menggunakan tarif INA-CBGs. Kinerja rumah sakit dihitung dan menjadi pertimbangan besaran budget tahun berikutnya.

BPJS Kesehatan telah melakukan uji coba mixed-method INA-CBGs dan Global Budget tahap 1 sejak tahun 2018 dengan menghitung besaran Global Budget 2019 bagi 2 (dua) RS di Kabupaten Tanah Datar, Sumatera Barat. Pada tahun 2019 terdapat perluasan wilayah uji coba 
dengan menambah 4 (empat) kabupaten/kota sehingga RS yang terlibat dalam studi berjumlah 30 RS di 5 kabupaten/kota. Tujuan dari studi tahap 1 ini adalah untuk menguji coba metode penghitungan global budget dan mengidentifikasi tantangan yang dihadapi bila kebijakan mixed method INA-CBGs dan Global Budget ini diberlakukan.

\section{Metode Penelitian}

Penelitian ini merupakan penelitian operasional. Penghitungan global budget didasarkan pada proyeksi jumlah peserta, jumlah kunjungan, casemix dan casemix index (CMI). Status kepemilikan RS, tipe RS, kapasitas rumah sakit (ketersediaan tempat tidur, SDM, dan fasilitas RS) juga dipertimbangkan dalam penghitungan global budget.

Populasi dalam kajian ini adalah semua rumah sakit yang bekerjasama dengan BPJS dan sebagai sampelnya adalah seluruh RS yang menjadi mitra BPJS Kesehatan di 5 Kabupaten/Kota. Pada tahap pertama ini BPJS Kesehatan telah melakukan uji coba sejak tahun 2018 dengan menghitung besaran Global Budget tahun 2019 bagi 2 rumah sakit di Kabupaten Tanah Datar. Pada tahun 2019 terdapat perluasan wilayah uji coba dengan menambah 4 kabupaten/kota sehingga rumah sakit yang terlibat dalam kajian ini berjumlah 30 RS yang tersebar di Kabupaten Tanah Datar, Kabupaten Gorontalo, Kabupaten Sumedang, Kabupaten Kulonprogo, dan Kota Bogor.

Global budget tahun 2020 dihitung pada akhir tahun 2019 dengan menggunakan datapelayanan kesehatan tahun Januari 2017-Juli 2019 dan belum ada penerapan risiko apapun pada RS. Analisis dilakukan dengan membandingkan hasil penghitungan Global Budget dengan realisasi klaim RS.

Kementerian Kesehatan belum mempublikasikan besaran cost weight dan hospital base rate (HBR) yang digunakan dalam membentuk tarif INA-CBGs saat ini. Cost weight dan HBR yang digunakan dalam penghitungan Global Budget ini dihitung berdasarkan tarif INACBGs tahun 2016 pada PMK Nomor 64 Tahun 2016 dan jumlah kasus per CBG pada data klaim JKN tahun 2014.

\section{Konsep Penghitungan Mixed Method INA- CBGs dan Global Budget}

Sistem pembayaran pelayanan kesehatan yang digunakan adalah mixed method INA- CBGs dan Global Budget sehingga dalam konsep penghitungan global budget dilakukan sesuai konteks kebijakan pembayaran INA-CBGs seperti dilihat pada bagan 1 .

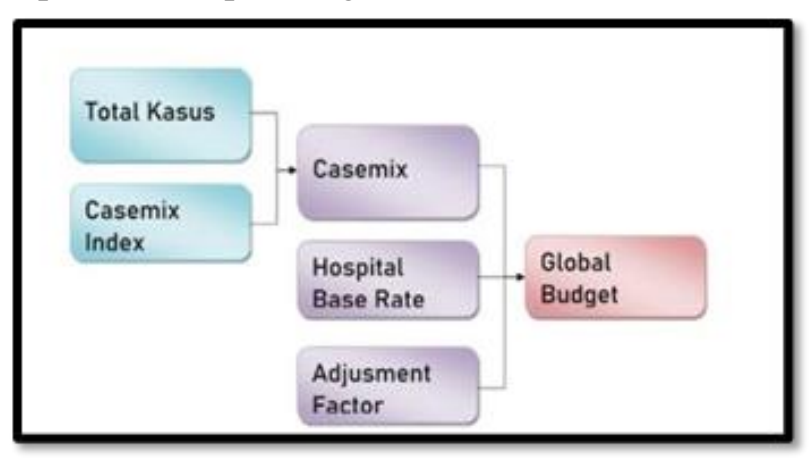

Bagan 1. Alur Penghitungan Global Budget

1. Casemix index (CMI) mencerminkan ratarata keparahan penyakit yang diderita oleh pasien di RS tertentu. Semakin tinggi CMI maka semakin tinggi pula rata-rata keparahan pasien yang ditangani oleh RS. Umumnya RS yang fasilitasnya lengkap dan canggih akan memiliki CMI yang lebih tinggi. Casemix index ini lazim digunakan oleh RS untuk memonitor efisiensi layanan RS. Setiap rumah sakit dapat menghitung angka CMI-nya. Casemix Index merupakan ratarata terbobot dari cost weight kasus-kasus yang dilayani oleh RS, dimana Cost weight adalah bobot biaya perawatan kasus CBG tertentu terhadap biaya perawatan kasus 
CBG lainnya. Semakin tinggi biaya perawatan sebuah kasus CBG maka akan semakin besar pula cost weight-nya. Demikian pula, semakin tinggi level severitynya maka akan semakin besar pula cost weight-nya (Murray, The CDI buzz about CMI: What your facility metrics mean, 2017) (Mendez, Harrington, Christen, \& Spellberg, 2014).

\section{Casemix}

Dalam pembayaran DRG atau CBG, aktivitas rumah sakit tidak hanya diukur menggunakan jumlah kunjungan namun juga menggunakan casemix. Casemix merupakan bauran kasus yang dilayani oleh rumah sakit. Angka casemix menunjukkan volume aktivitas rumah sakit secara lebih nyata karena mempertimbangkan jumlah kunjungan dan keparahan penyakit yang diderita pasien. Semakin banyak jumlah kasus semakin besar casemix nya. Semakin tinggi severity level kasus yang ditangani rumah sakit maka semakin besar casemix nya. Karena mencerminkan bauran keseluruhan kasus di RS, maka angka casemix ini juga menggambarkan sumber daya yang dibutuhkan oleh RS. Semakin besar casemix RS maka semakin besar pula sumber daya yang dibutuhkan. Setiap rumah sakit dapat menghitung angka casemix nya.

\section{Hospital Base Rate}

Pada tingkat nasional, Hospital Base Rate merupakan angka reference dalam moneter (rupiah) yang merujuk pada satu unit casemix atau kasus CBG dengan cost weight=1. Bila Hospital Base Rate Nasional dikalikan dengan cost weight maka akan terbentuk Tarif INA-CBGs. Hospital Base Rate Nasional inilah yang akan digunakan untuk menghitung Global Budget. Pada kebijakan INA-CBGs saat ini, besaran HBR dibedakan menurut Tipe Rumah Sakit yaitu Kelas A, B, C dan D

\section{Adjustment Factor}

Adjustment factor adalah variabel tambahan dalam formula penghitungan tarif $\mathrm{CBG}$ agar lebih adil. Adjustment factor dapat ditambahkan dalam formula penghitungan tarif CBG, misal letak geografis rumah sakit tipe rumah sakit, kepemilikan rumah sakit, dan regionalisasi tarif.

5. Besaran Global Budget

Seperti dijelaskan sebelumnya bahwa penghitungan besaran budget disesuaikan dengan volume aktifitas masing-masing rumah sakit atau casemix. Rumah sakit yang memiliki volume aktifitas/casemix tinggi akan membutuhkan sumber daya yang besar sehingga akan mendapatkan budget yang tinggi begitupun sebaliknya

Kotak 1. Formula dalam Penghitungan Global Budget

$$
\begin{aligned}
& \text { Casemix Index }=\frac{\sum(\text { Cost Weight } x \text { Jumlah Kasus })}{\text { Total Kasus }} \\
& \text { Casemix }=\text { Casemix Index } x \text { Total Kasus } \\
& \text { Budget RS }=\text { HBR Nasional } x \text { Casemix } x \text { Adj Factor } \\
& \text { Catatan: } \\
& \text { Nilai cost weight, HBR Nasional dan Adjustment Factor } \\
& \text { berlaku secara nasional, dihitung berdasarkan tarif INA- } \\
& \text { CBGs PMK Nomor } 64 \text { Tahun } 2016 \text { dan jumlah kasus per } \\
& \text { CBG data klaim JKN tahun } 2014 .
\end{aligned}
$$

Besaran global budget juga akan dipengaruhi oleh kapasitas yang dimiliki oleh rumah sakit seperti jumlah tempat tidur, SDM, dan fasilitas Kesehatan. Penghitungan proyeksi jumlah kunjungan dilakukan pada tingkat rumah sakit. 
Hasil

Tabel 1. Perbandingan Variabel dalam Prediksi Penghitungan Global Budget 2019 dan Realisasi Klaim 2019 di Kabupaten Tanah Datar

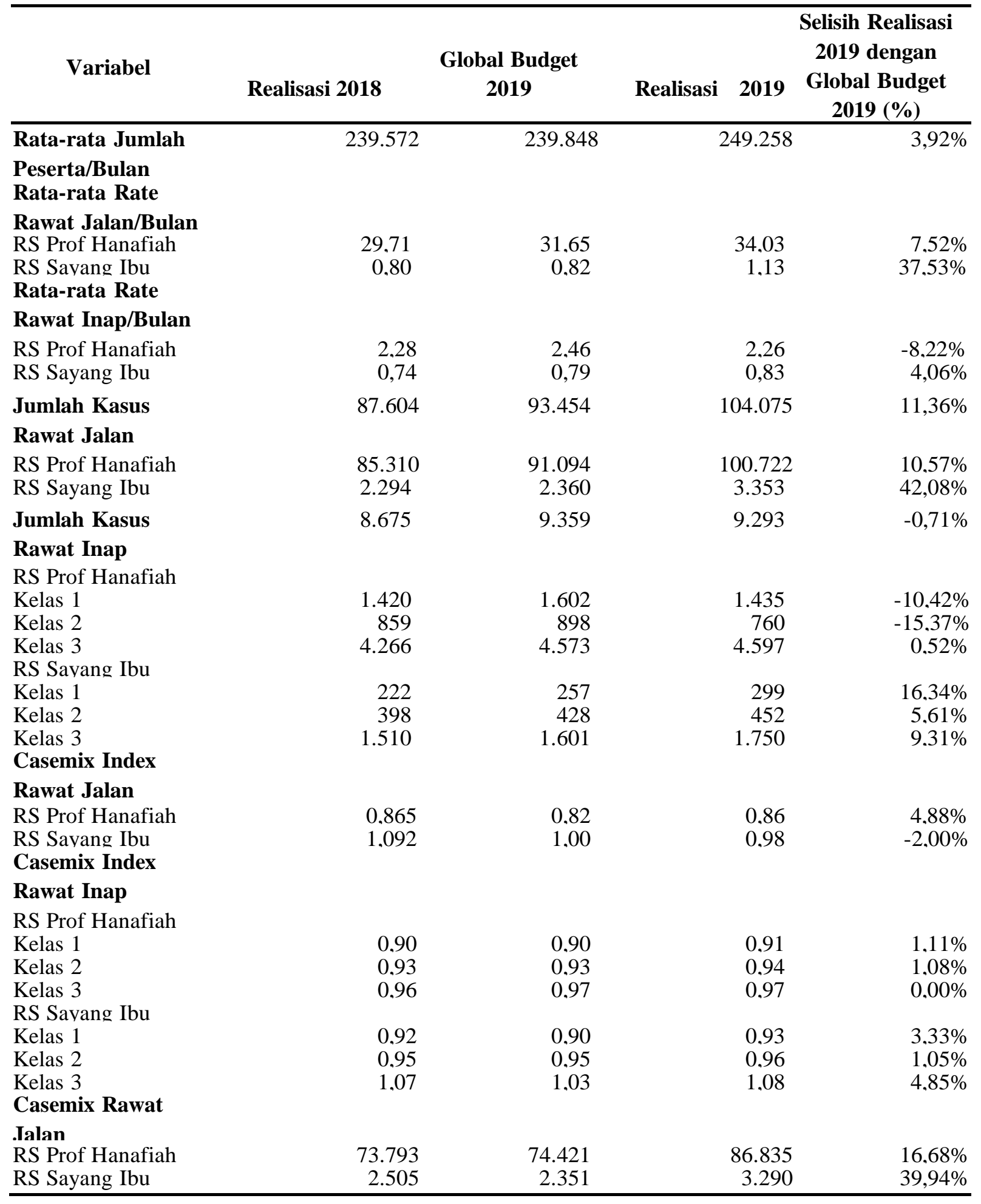




\begin{tabular}{|c|c|c|c|c|}
\hline \multicolumn{5}{|l|}{ Casemix Rawat } \\
\hline \multicolumn{5}{|l|}{ RS Prof Hanafiah } \\
\hline Kelas 1 & 1.278 & 1.442 & 1.306 & $-9,43 \%$ \\
\hline Kelas 2 & 799 & 840 & 714 & $-15,00 \%$ \\
\hline Kelas 3 & 4.095 & 4.433 & 4.466 & $0,74 \%$ \\
\hline \multicolumn{5}{|l|}{ RS Savang Ibu } \\
\hline Kelas 1 & 204 & 230 & 278 & $20.87 \%$ \\
\hline Kelas 2 & 378 & 406 & 432 & $6.40 \%$ \\
\hline Kelas 3 & 1.616 & 1.649 & 1.888 & $14.49 \%$ \\
\hline Global Budget CBG & Rp 37.743.056.900 & Rp58.657.818.288 & Rp59.182.723.700 & $0,89 \%$ \\
\hline RS Prof Hanafiah & Rp 29.287.848.900 & Rp49.166.229.697 & Rp48.845.145.400 & $-0,65 \%$ \\
\hline RS Sayang Ibu & Rp 8.455.208.000 & Rp9.491.588.591 & Rp10.337.578.300 & $8,91 \%$ \\
\hline
\end{tabular}

Pada global budget 2019 di Kabupaten Tanah Datar, terdapat kenaikan jumlah peserta dari yang diprediksikan saat penghitungan global budget tahun 2019 terhadap realisasinya sebesar 3,9\%. Realisasi jumlah kasus rawat jalan juga mengalami selisih positif sebesar $11,4 \%$ sementara realisasi jumlah kasus rawat inap mengalami selisih negatif sebesar $0,7 \%$ dari prediksi jumlah kasus saat penghitungan global budget 2019. Besaran realisasi casemix index baik rawat inap maupun rawat jalan tidak berbeda jauh dengan besaran casemix index yang diprediksi saat penghitungan global budget 2019 dengan kisaran selisih $0,7 \%$ hingga $5,1 \%$. Terdapat selisih antara besaran global budget 2019 dengan realisasi klaim 2019 sebesar 0,9\% di kabupaten Tanah Datar dimana realisasi klaim lebih besar daripada besaran global budget. Realisasi klaim RS Prof. Hanafiah lebih kecil $0,7 \%$ dari besaran global budget sementara realisasi klaim RS Sayang Ibu lebih besar 8,9\% dari budget yang telah disepakati. Penjelasan lebih rinci perbandingan antara global budget dengan realisasi klaim 2019 dapat dilihat pada tabel 1.

Berbeda dengan global budget 2019, terdapat selisih yang cukup besar antara penghitungan global budget 2020 dengan realisasinya. Realisasi jumlah peserta jauh lebih rendah dibanding dengan angka yang digunakan saat penghitungan global budget dengan selisih berkisar antara 5,5\%-9,1\%. Selain itu realisasi jumlah kunjungan rawat jalan juga jauh lebih rendah dibanding global budget yang terjadi di semua kabupaten/kota (36,9\% hingga 50,1\%) dan hampir di seluruh rumah sakit kecuali 1 RS di Kabupaten Tanah Datar, 1 RS di Kabupaten Sumedang, dan 1 RS di Kabupaten Kulonprogo. Selisih ini bervariasi antar RS berkisar antara $-57 \%$ hingga $147 \%$. Terdapat selisih Realisasi Casemix Index yang juga cukup lebar bila dibandingkan dengan penghitungan global budget 2020. Selisih ini sangat bervariasi antar rumah sakit, beberapa RS mengalami selisih negatif sedangkan yang lainnya mengalami selisih positif dengan kisaran dari $15 \%$ hingga $75 \%$. Selisih pada jumlah kunjungan rawat jalan dan juga casemix index akan mengakibatkan selisih pula pada besaran casemix di rumah sakit. Selisih realisasi casemix bervariasi antar rumah sakit dengan kisaran $58 \%$ hingga $412 \%$ seperti yang ditunjukkan pada Tabel 2. 
Tabel 2. Perbandingan Variabel Rawat Jalan dalam Penghitungan Global Budget 2020 dan Realisasi Klaim 2020 di 5 Kabupaten/Kota

\begin{tabular}{|c|c|c|c|c|}
\hline Variabel & $\begin{array}{c}\text { Global Budget } \\
2020\end{array}$ & $\begin{array}{l}\text { Realisasi } 2020 \\
\quad(\text { sd Nov) }\end{array}$ & Selisih (\%) & $\begin{array}{c}\text { Sebaran Selisih } \\
\text { di RS }(\%)\end{array}$ \\
\hline \multicolumn{5}{|c|}{ Rata-rata Jumlah Peserta/bulan (*s/d September) } \\
\hline Kabupaten Tanah Datar & 260.631 & 246.251 & $-5,5 \%$ & \\
\hline Kabupaten Gorontalo & 317.651 & 297.887 & $-6,2 \%$ & \\
\hline Kabupaten Sumedang & 795.078 & 744.345 & $-6,4 \%$ & \\
\hline Kabupaten Kulonprogo & 385.764 & 357.792 & $-7,3 \%$ & \\
\hline Kota Bogor & 789.755 & 717.773 & $-9,1 \%$ & \\
\hline \multicolumn{5}{|c|}{ Jumlah Kasus Rawat Jalan } \\
\hline Kabupaten Tanah Datar & 108.465 & 67.284 & $-38,0 \%$ & $-40 \%-13 \%$ \\
\hline Kabupaten Gorontalo & 48.467 & 24.165 & $-50,1 \%$ & $-55 \%-(-42 \%)$ \\
\hline Kabupaten Sumedang & 218.946 & 121.330 & $-44,6 \%$ & $-56 \%-147 \%$ \\
\hline Kabupaten Kulonprogo & 141.705 & 94.428 & $-33,4 \%$ & $-26 \%-18 \%$ \\
\hline Kota Bogor & 1.282 .137 & 808.842 & $-36,9 \%$ & $-57 \%-(-32 \%)$ \\
\hline \multicolumn{5}{|c|}{ Casemix Index Rawat Jalan } \\
\hline Kabupaten Tanah Datar & 0,96 & 0,96 & $0,6 \%$ & $-7 \%-9 \%$ \\
\hline Kabupaten Gorontalo & 1,21 & 1,08 & $-10,8 \%$ & $-15 \%-(-8 \%)$ \\
\hline Kabupaten Sumedang & 0,90 & 1,42 & $57,5 \%$ & $26 \%-75 \%$ \\
\hline Kabupaten Kulonprogo & 0,93 & 0,97 & $5,1 \%$ & $-1 \%-9 \%$ \\
\hline Kota Bogor & 0,94 & 0,99 & $5,5 \%$ & $-3 \%-23 \%$ \\
\hline \multicolumn{5}{|l|}{ Casemix Rawat Jalan } \\
\hline Kabupaten Tanah Datar & $47.059,50$ & $31.716,32$ & $-32,6 \%$ & $-34 \%-6 \%$ \\
\hline Kabupaten Gorontalo & $30.617,50$ & $13.455,37$ & $-56,1 \%$ & $-58 \%-(-50 \%)$ \\
\hline Kabupaten Sumedang & $70.077,00$ & $53.715,58$ & $-23,3 \%$ & $89 \%-412 \%$ \\
\hline Kabupaten Kulonprogo & $18.962,00$ & $14.038,29$ & $-26,0 \%$ & $-16 \%-8 \%$ \\
\hline Kota Bogor & $80.525,93$ & $54.263,60$ & $-32,6 \%$ & $-58 \%-21 \%$ \\
\hline
\end{tabular}

Tabel 3. Perbandingan Varibel Rawat Inap dalam Penghitungan Global Budget 2020 dan Realisasi Klaim 2020 di 5 Kabupaten/Kota

\begin{tabular}{lrrcc}
\hline \multicolumn{1}{c}{ Variabel } & $\begin{array}{c}\text { Global Budget } \\
\mathbf{2 0 2 0}\end{array}$ & $\begin{array}{r}\text { Realisasi 2020 } \\
\text { (sd Nov) }\end{array}$ & Selisih (\%) & $\begin{array}{c}\text { Sebaran Selisih di RS } \\
(\%)\end{array}$ \\
\hline $\begin{array}{l}\text { Jumlah Kasus Rawat Inap } \\
\text { Kabupaten Tanah Datar }\end{array}$ & & & & \\
Kelas 1 & 2.393 & 977 & $-59,2 \%$ & $-66 \%-(-56 \%)$ \\
Kelas 2 & 2.232 & 781 & $-65,0 \%$ & $-74 \%-(-47 \%)$ \\
Kelas 3 & 6.969 & 5.111 & $-26,7 \%$ & $-39 \%-1 \%$ \\
Kabupaten Gorontalo & & & & $-48 \%-0 \%$ \\
Kelas 1 & 1.721 & 1.221 & $-29,1 \%$ & $-71 \%-(-64 \%)$ \\
Kelas 2 & 3.198 & 1.031 & $-67,8 \%$ & $-59 \%-(-25 \%)$ \\
Kelas 3 & 10.960 & 6.669 & $-39,2 \%$ & \\
& & & & \\
\hline
\end{tabular}




\begin{tabular}{|c|c|c|c|c|}
\hline \multicolumn{5}{|c|}{ Kabupaten Sumedang } \\
\hline Kelas 1 & 7.474 & 3.448 & $-53,9 \%$ & $-57 \%-137 \%$ \\
\hline Kelas 2 & 7.678 & 3.443 & $-55,2 \%$ & $-59 \%-91 \%$ \\
\hline Kelas 3 & 19.596 & 12.464 & $-36,4 \%$ & $-41 \%-195 \%$ \\
\hline \multicolumn{5}{|c|}{ Kabupaten Kulonprogo } \\
\hline Kelas 1 & 2.673 & 1.579 & $-40,9 \%$ & $-100 \%-(-52 \%)$ \\
\hline Kelas 2 & 2.652 & 2.194 & $-17,3 \%$ & $-100 \%-(-42 \%)$ \\
\hline Kelas 3 & 14.032 & 8.720 & $-37,9 \%$ & $-43 \%-(-15 \%)$ \\
\hline \multicolumn{5}{|c|}{ Kota Bogor } \\
\hline Kelas 1 & 23.969 & 17.476 & $-27,1 \%$ & $-46 \%-(-20 \%)$ \\
\hline Kelas 2 & 28.473 & 8.988 & $-68,4 \%$ & $-77 \%-(-67 \%)$ \\
\hline Kelas 3 & 58.288 & 36.880 & $-36,7 \%$ & $-60 \%-(-55 \%)$ \\
\hline \multicolumn{5}{|c|}{ Casemix Index Rawat Inap } \\
\hline \multicolumn{5}{|c|}{ Kabupaten Tanah Datar } \\
\hline Kelas 1 & 0,92 & 1,05 & $14,9 \%$ & $14 \%-15 \%$ \\
\hline Kelas 2 & 0,95 & 1,03 & $7,9 \%$ & $3 \%-13 \%$ \\
\hline Kelas 3 & 0,98 & 1,14 & $15,8 \%$ & $16 \%-15 \%$ \\
\hline \multicolumn{5}{|c|}{ Kabupaten Gorontalo } \\
\hline Kelas 1 & 0,45 & 1,08 & $138,8 \%$ & $0 \%-39 \%$ \\
\hline Kelas 2 & 0,72 & 0,76 & $5,0 \%$ & $12 \%-0 \%$ \\
\hline Kelas 3 & 0,78 & 0,78 & $-0,2 \%$ & $0 \%-0 \%$ \\
\hline \multicolumn{5}{|c|}{ Kabupaten Sumedang } \\
\hline Kelas 1 & 0,87 & 0,81 & $-7,5 \%$ & $-3 \%-6 \%$ \\
\hline Kelas 2 & 0,84 & 0,81 & $-4,0 \%$ & $-3 \%-9 \%$ \\
\hline Kelas 3 & 0,83 & 0,83 & $-0,2 \%$ & $1 \%-10 \%$ \\
\hline \multicolumn{5}{|c|}{ Kabupaten Kulonprogo } \\
\hline Kelas 1 & 0,62 & 0,87 & $39,9 \%$ & $-100 \%-31 \%$ \\
\hline Kelas 2 & 0,69 & 0,82 & $18,6 \%$ & $-100 \%-0 \%$ \\
\hline Kelas 3 & 0,86 & 0,86 & $0,4 \%$ & $-100 \%-(-8 \%)$ \\
\hline \multicolumn{5}{|c|}{ Kota Bogor } \\
\hline Kelas 1 & 0,94 & 1,02 & $8,5 \%$ & $8 \%-20 \%$ \\
\hline Kelas 2 & 0,92 & 0,92 & $0,3 \%$ & $1 \%-(-3 \%)$ \\
\hline Kelas 3 & 0,99 & 0,99 & $0,2 \%$ & $1 \%-1 \%$ \\
\hline \multicolumn{5}{|c|}{ Casemix Rawat Inap } \\
\hline \multicolumn{5}{|c|}{ Kabupaten Tanah Datar } \\
\hline Kelas 1 & $1.094,50$ & 516,38 & $-52,8 \%$ & $-61 \%-(-50 \%)$ \\
\hline Kelas 2 & $1.063,50$ & 400,13 & $-62,4 \%$ & $-71 \%-(-45 \%)$ \\
\hline Kelas 3 & $3.419,50$ & $2.902,32$ & $-15,1 \%$ & $-30 \%-19 \%$ \\
\hline \multicolumn{5}{|c|}{ Kabupaten Gorontalo } \\
\hline Kelas 1 & 858,50 & 709,47 & $-17,4 \%$ & $-100 \%-(-34 \%)$ \\
\hline Kelas 2 & $1.064,50$ & 397,32 & $-62,7 \%$ & $-69 \%-(-58 \%)$ \\
\hline Kelas 3 & $6.110,00$ & $2.772,57$ & $-54,6 \%$ & $-59 \%-(-53 \%)$ \\
\hline \multicolumn{5}{|c|}{ Kabupaten Sumedang } \\
\hline Kelas 1 & $2.440,63$ & 985,68 & $-59,6 \%$ & $-58 \%-166 \%$ \\
\hline Kelas 2 & $2.473,43$ & 969,80 & $-60,8 \%$ & $-63 \%-118 \%$ \\
\hline Kelas 3 & $5.989,40$ & $3.738,78$ & $-37,6 \%$ & $-40 \%-238 \%$ \\
\hline \multicolumn{5}{|c|}{ Kabupaten Kulonprogo } \\
\hline Kelas 1 & 376,82 & 271,78 & $-27,9 \%$ & $-100 \%-(-37 \%)$ \\
\hline Kelas 2 & 347,24 & 285,11 & $-17,9 \%$ & $-100 \%-(-42 \%)$ \\
\hline Kelas 3 & $1.884,22$ & $1.132,87$ & $-39,9 \%$ & $-49 \%-(-13 \%)$ \\
\hline
\end{tabular}




\begin{tabular}{|c|c|c|c|c|}
\hline \multicolumn{5}{|l|}{ Kota Bogor } \\
\hline Kelas 1 & $1.493,93$ & $1.201,16$ & $-19,6 \%$ & $-49 \%-(-20 \%)$ \\
\hline Kelas 2 & $1.705,40$ & 535,34 & $-68,6 \%$ & $-68 \%-(-73 \%)$ \\
\hline Kelas 3 & $3.871,80$ & $2.471,54$ & $-36,2 \%$ & $-60 \%-(-59 \%)$ \\
\hline
\end{tabular}

Hampir sama dengan kondisi rawat jalan, realisasi jumlah kunjungan rawat inap tahun 2020 juga jauh lebih rendah dibanding dengan penghitungan global budget, yang terjadi di semua kabupaten/kota di semua kelas kamar perawatan dengan kisaran 17,3\% - 68,4\%. Namun demikian terdapat beberapa RS yang mengalami peningkatan jumlah kunjungan rawat inap sehingga terdapat selisih positif dengan penghitungan global budget. Hampir di semua kabupaten/kota realisasi Casemix Index nya lebih besar dari penghitungan global budget. Selisih pada jumlah kunjungan rawat jalan dan juga casemix index akan mengakibatkan selisih pula pada besaran casemix di rumah sakit. Realisasi casemix rawat inap tahun 2020 juga jauh lebih rendah dibandingkan dengan angka penghitungan global budget. Hal ini ditemukan di seluruh kabupaten/kota, walaupun demikian terdapat 1 rumah sakit di Kabupaten Sumedang yang realisasi casemix nya melebihi penghitungan global budget. Informasi lebih rinci dapat dilihat pada tabel 3.

\section{Tabel 4. Perbandingan Besaran Global Budget 2020 dan Realisasi Klaim 2020 di 5 Kabupaten/Kota}

\begin{tabular}{llrlrrr}
\hline \multicolumn{1}{c}{ Kabupaten/Kota } & \multicolumn{1}{c}{ Global Budget 2020 } & \multicolumn{2}{c}{$\begin{array}{c}\text { Realisasi 2020 } \\
\text { (sd Nov) }\end{array}$} & Selisih (\%) & $\begin{array}{c}\text { Sebaran Selisih } \\
\text { di RS (\%) }\end{array}$ \\
\hline Kabupaten Tanah Datar & $\mathrm{Rp}$ & 71.514 .008 .338 & $\mathrm{Rp}$ & 43.496 .577 .800 & $-39,2 \%$ & $-45 \%-(-17 \%)$ \\
Kabupaten Gorontalo & $\mathrm{Rp}$ & 88.905 .006 .584 & $\mathrm{Rp}$ & 42.613 .954 .382 & $-52,1 \%$ & $-55 \%-(-42 \%)$ \\
Kabupaten Sumedang & $\mathrm{Rp}$ & 217.444 .544 .160 & $\mathrm{Rp}$ & 120.754 .017 .575 & $-44,5 \%$ & $-49 \%-147 \%$ \\
Kabupaten Kulonprogo & $\mathrm{Rp}$ & 115.402 .356 .626 & $\mathrm{Rp}$ & 81.697 .530 .145 & $-29,2 \%$ & $-32 \%-(-15 \%)$ \\
Kota Bogor & $\mathrm{Rp}$ & 843.575 .519 .187 & $\mathrm{Rp}$ & 531.392 .750 .469 & $-37,0 \%$ & $-44 \%-(-38 \%)$ \\
\hline
\end{tabular}

Tabel 4 menunjukkan realisasi klaim 2020 dibandingkan penghitungan global budget 2020 . Terlihat bahwa realisasi klaim di semua kabupaten/kota lebih kecil dari penghitungan global budget. Sampai dengan November 2020, terdapat selisih sebesar 29,2\% hingga 52,1\%. Dengan kata lain realisasinya hanya sebesar $47,9 \%$ hingga $70,8 \%$ dari budget yang telah disepakati.

Pelaksanaan evaluasi uji coba tidak hanya dilakukan pada besaran realisasi klaim dengan besaran global budget, melainkan dilakukan juga terhadap variable-variabel yang membentuk hitungan global budget, yaitu jumlah peserta, jumlah kunjungan dan casemix index. Disamping itu, monitoring juga dilakukan pada capaian indikator-indikator kinerja rumah sakit yaitu kejadian infeksi nosokomial, readmisi, pulang atas permintaan sendiri, rujukan horizontal FKRTL, realisasi kunjungan, rate, casemix, casemix index, realisasi budget, ketersediaan SDM dan sarana prasarana, ketersediaan dokumen panduan praktik klinis dan walk through audit.

Kantor Cabang memberikan umpan balik setiap bulan dengan informasi pencapaian 
indikator kinerja. Standar yang digunakan mengacu pada Kajian Metode Pembayaran Berbasis Kinerja Berdasarkan Indikator Kualitas Layanan di FKRTL Tahun 2017.

1. Standar infeksi nosokomial $\leq 1,5 \%$ mengacu pada peraturan Kepmenkes No 129. Infeksi nosokomial adalah yang dialami oleh pasien yang diperoleh selama dirawat di RS yang meliputi decubitus, phlebitis, dan infeksi luka operasi.

2. Kriteria readmisi yaitu jangka waktu admisi kurang dari atau sama dengan 30 hari baik di RS yang sama atau RS yang berbeda, diagnosis utama yang sama dengan diagnosa utama sebelumnya, atau diagnosis utama yang sama dengan diagnosis sekunder sebelumnya, atau CBG prosedur yang sama dengan CBG prosedur sebelumnya tanpa memperhatikan severity level. Standar untuk readmisi yaitu $1,73 \%$

3. Persentase kejadian pulang atas permintaan sendiri maksimum 5\%

4. Kriteria rujukan horizontal berlaku pada rujukan antara RS kelas yang sama, dan jangka waktu RITL pertama dengan RITL rujukan adalah $\leq \mathrm{N}+1$, sedangkan untuk jangka waktu RJTL antara kunjungan pertama dengan kunjungan rujukan berikutnya adalah $\leq 30$ hari. Standarnya rata-rata persentase kejadian rujukan horizontal rawat inap adalah $1,34 \%$, sedangkan rata-rata persen jumlah rujukan untuk kasus rawat jalan adalah 2,95\%.

Terlihat pada tabel 5 bahwa semua RS di 5 kabupaten/kota telah memenuhi 4 indikator yang telah ditetapkan yaitu kejadian infeksi nosokomial, rujukan horizontal FKRTL baik rawat jalan maupun rawat inap, dan pulang atas permintaan sendiri. Namun demikian, indikator readmisi belum dipenuhi oleh semua RS di Kabupaten Tanah Datar, Kabupaten Gorontalo, dan Kabupaten Sumedang dimana tingkat readmisi nya melebihi $1,73 \%$. Sementara itu terdapat 57\% RS di Kabupaten Kulonprogo dan $27 \%$ RS di Kota Bogor yang readmisinya kurang dari $1,73 \%$.

\section{Tabel 5. Capaian Indikator Hospital Value Based per Bulan di Rumah Sakit}

\begin{tabular}{lc}
\hline \multicolumn{1}{c}{ Indikator } & $\begin{array}{c}\text { Capaian Indikator } \\
\text { per Bulan }\end{array}$ \\
\hline Infeksi Nosokomial & $100 \%$ \\
Kabupaten Tanah Datar & $100 \%$ \\
Kabupaten Gorontalo & $100 \%$ \\
Kabupaten Sumedang & $100 \%$ \\
Kabupaten Kulonprogo & $100 \%$ \\
Kota Bogor & \\
Readmisi & $0 \%$ \\
Kabupaten Tanah Datar & $0 \%$ \\
Kabupaten Gorontalo & $0 \%$ \\
Kabupaten Sumedang & $57 \%$ \\
Kabupaten Kulonprogo & $27 \%$ \\
Kota Bogor & \\
Rujukan Horisontal Rawat Jalan & \\
Kabupaten Tanah Datar & $100 \%$ \\
Kabupaten Gorontalo & $100 \%$ \\
Kabupaten Sumedang & $100 \%$ \\
\hline
\end{tabular}




\begin{tabular}{ll}
\hline Kabupaten Kulonprogo & $100 \%$ \\
Kota Bogor & $100 \%$ \\
Rujukan Horisontal Rawat Inap & \\
Kabupaten Tanah Datar & $100 \%$ \\
Kabupaten Gorontalo & $100 \%$ \\
Kabupaten Sumedang & $100 \%$ \\
Kabupaten Kulonprogo & $100 \%$ \\
Kota Bogor & $100 \%$ \\
Pulang Atas Permintaan Sendiri & \\
Kabupaten Tanah Datar & $100 \%$ \\
Kabupaten Gorontalo & $100 \%$ \\
Kabupaten Sumedang & $100 \%$ \\
Kabupaten Kulonprogo & $100 \%$ \\
Kota Bogor & $100 \%$ \\
\hline
\end{tabular}

\section{Pembahasan}

Pada global budget 2019, selisih antara besaran budget dengan realisasi klaim cukup rendah bahkan dibawah $1 \%$ pada tingkat kabupaten, walaupun selisih di tingkat RS melebihi 5\% pada RS Sayang Ibu. Hal ini terjadi karena terdapat pergeseran/shifting pasien dari RS Prof. Hanafiah ke RSIA Sayang Ibu khususnya pada kasus Ibu dan Anak bertepatan dengan pengembangan layanan di rawat jalan dan fasilitas di RSIA Sayang Ibu berupa penambahan jumlah tempat tidur di Kelas 1 sehingga mampu melayani lebih banyak pasien dari sebelumnya. Pengembangan layanan di RSIA Sayang Ibu ini tidak serta merta meningkatkan kapasitas RS dari aspek kemampuannya menangani kasus yang lebih parah karena realisasi CMI nya relatif tetap dibandingkan saat penghitungan global budget. Rendahnya realisasi casemix rawat inap RS Prof. Hanafiah akibat rendahnya jumlah kunjungan rawat inap diimbangi dengan tingginya casemix rawat jalan. Tingginya realisasi casemix rawat jalan (lebih tinggi 5,1\% dari global budget) disebabkan oleh adanya penambahan fasilitas Hemodialisis di tahun berjalan yang sebelumnya tidak dimiliki oleh RS. Temuan ini menunjukkan bahwa pada kondisi yang normal, global budget dapat dihitung menggunakan metodologi yang telah ditetapkan. Selain itu penghitungan global budget di tingkat kabupaten/kota lebih bagus hasilnya dibandingkan dengan menghitung global budget langsung di tingkat RS karena mengakomodir shifting pasien dari RS yang satu ke RS yang lainnya karena perubahan kapasitas RS.

Terdapat pergeseran yang cukup signifikan antara budget 2020 yang sudah dihitung sebelumnya dengan realisasi klaimnya. Hal ini disebabkan oleh beberapa variabel kunci yaitu jumlah peserta, jumlah kunjungan, casemix dan casemix index seperti dijelaskan di bawah ini.

a. Jumlah Peserta

Jumlah peserta merupakan variabel yang sangat krusial karena variable ini sangat terkait erat dengan jumlah kunjungan yang akan terjadi. Disamping jumlah peserta secara total, jumlah peserta menurut hak kelas kamar juga menjadi penting mengingat besaran klaim akan berbeda sesuai dengan hak kelas rawat.

Dari hasil evaluasi diketahui bahwa terdapat selisih negatif antara prediksi jumlah peserta dengan realisasinya di semua kabupaten kota serta terjadi perubahan pola persebaran jumlah peserta menurut hak kelas rawat. Hampir di semua kabupaten kota terjadi kenaikan proporsi peserta kelas 3 kecuali di Kota Bogor. Hal ini terjadi karena 
kenaikan Iuran pada kelas 1 dan kelas 2 . Sementara itu di Kota Bogor terjadi kenaikan proporsi peserta kelas 1 akibat perpindahan peserta dari kelas 2 ke kelas 1 menyusul adanya kebijakan kenaikan UMR di wilayah tersebut. Selain itu kenaikan iuran dan kondisi pandemi juga mempengaruhi kemampuan membayar peserta khususnya PBPU.

b. Jumlah Kunjungan

Jumlah kunjungan sangat dipengaruhi oleh jumlah peserta. Bergesernya realisasi jumlah peserta dibandingkan dengan prediksinya membuat prediksi jumlah kunjungan yang dihitung sebelumnya tidak tercapai. Disamping itu terdapat perubahan proporsi jumlah kunjungan menurut hak kelas rawat diakibatkan perubahan proporsi jumlah peserta. Sebagai contoh proporsi jumlah kunjungan rawat inap di kelas 2 mengalami penurunan yang cukup tajam diiringi kenaikan kunjungan rawat inap di kelas 1 , sesuai perubahan proporsi jumlah peserta menurut hak kelas rawat.

Selain penurunan jumlah peserta, adanya pancemi Covid-19 memberikan dampak yang sangat besar bagi rumah sakit. Terjadi penurunan jumlah kunjungan di rumah sakit secara signifikan. Penurunan jumlah kunjungan bervariasi antar kabupaten kota. Penurunan jumlah kunjungan rawat inap terbesar hingga mencapai $50 \%$ dan hingga 90\% pada rawat jalan di bulan April 2020. Pada bulan September 2020, jumlah kunjungan rawat inap dan rawat jalan berkisar 40-60\% dari angka yang semestinya.

Terdapat fenomena yang sama di semua kabupaten kota dimana RS mengalami penurunan jumlah kasus JKN baik rawat inap maupun rawat jalan terutama pada RS Rujukan Covid (biasanya RSUD dan RS swasta terpilih). Hal ini disebabkan karena masyarakat enggan periksa ke RS bila tidak dalam kondisi darurat, masyarakat yang menderita penyakit non covid enggan periksa di RS rujukan covid, tutupnya poli karena dokter spesialisnya berusia lanjut, ditutupnya RS (baik poli rawat jalan maupun IGD) selama beberapa hari karena Nakes terinfeksi Covid serta kebijakan Pemda yang mengatur RS Rujukan Covid hanya menerima pasien Covid

Uniknya terdapat beberapa RS yang jumlah kunjungannya relatife tetap bahkan mengalami peningkatan di masa pandemi. Hampir semua RS khusus Ibu dan Anak memiliki jumlah kunjungan yang tetap bahkan meningkat karena terdapat shifting pasien Ibu dan Anak yang biasanya datang ke RSUD (RS Rujukan Covid) beralih ke RSIA. Hal ini terlihat dari turunnya proporsi kasus persalinan di RSUD. Disamping itu kasus persalinan merupakan kasus yang penanganannya tidak dapat ditunda sehingga mengharuskan pasien untuk datang ke RS. Namun demikian terdapat beberapa RSU yang meningkat jumlah kunjungannya baik rawat inap maupun rawat jalan karena melakukan pengembangan layanan dan fasilitas yang signifikan pada tahun berjalan. Rumah Sakit Nyi Ageng Serang Kulonprogo membuka pelayanan rawat inap kelas 1 dan kelas 2 pada tahun 2020 dimana sebelumnya hanya memiliki pelayanan kelas 3 saja. Rumah Sakit Harapan Keluarga Sumedang juga mengembangkan pelayanan rawat jalan dan rawat inapnya sehingga realisasi kunjungannya melebihi penghitungan global budget

c. Casemix dan Casemix Index

Terdapat selisih realisasi CMI 2020 dengan prediksinya yang digunakan untuk menghitung global budget. Selisih CMI ini bervariasi antar rumah sakit, sebagian RS 
memiliki realisasi yang lebih kecil namun yang lainnya memiliki realisasi CMI yang lebih besar yang disebabkan oleh:

1) Penambahan dan pengurangan dokter spesialis dan alat medik selama tahun berjalan. Hal ini sangat terkait dengan kebijakan diijinkannya dokter praktek di 3 RS yang berbeda dalam waktu yang bersamaan. Beberapa RS menambah dokter spesialis misal dokter mata, dokter jantung, dokter urologi dan lain sebagainya. Penambahan dokter ini akan mempengaruhi jumlah kunjungan ke rumah sakit dan juga CMI nya karena dengan adanya dokter tersebut maka RS akan melayani kasus- kasus yang belum pernah dilayani sebelumnya baik kasus rawat jalan maupun rawat inap. Biasanya hal ini akan membuat CMI di rumah sakit tersebut meningkat. Di lain pihak, ada RS yang ditinggalkan oleh dokter spesialisnya sehingga kapasitasnya berkurang dan tidak ada lagi kasus-kasus tertentu terkait dengan dokter spesialis tersebut. Hal ini lah yang membuat realisasi CMI di RS lebih rendah dibanding penghitungan global budget. Penambahan dan pengurangan kapasitas ini terjadi di seluruh kabupaten/ kota. Pengadaan dan pengurangan kasus operasi katarak dan hemodialisis biasanya menjadi pemicu tinggi atau rendahnya realisasi CMI rawat jalan. Sebagai contoh penutupan sementara unit Hemodialisis di RS Dunda Gorontalo menyebabkan rendahnya realisasi CMI rawat jalan.

2) Perubahan Tipe RS pada tahun berjalan. Terdapat beberapa RS yang berganti tipe pada tahun 2020, yang awalnya tipe D menjadi tipe C (RS Ainun Habibie), dan ada pula dari $\mathrm{C}$ menjadi $\mathrm{B}$.
Perubahan tipe ini akan berdampak langsung pada nilai cost weight dan hospital base rate yang digunakan dalam penghitungan budget karena tarif INACBGs berbeda menurut Tipe RS. Selain perubahan tipe kelas ada rumah sakit yang memperluas layanan tidak hanya khusus saja namun dapat melayani secara umum.

3) Perubahan kapasitas tempat tidur RS di tahun berjalan. Beberapa RS mengembangkan kapasitas RS dengan mengadakan kelas perawatan 1 dan 2 yang sebelumnya hanya melayani kelas 3 sehingga mempengaruhi casemix di masing- masing kelas kamar perawatan.

4) Perubahan jenis layanan yang diakses oleh peserta JKN. Terjadi perubahan pola utilisasi layanan Kesehatan pada saat pandemi Covid-19. Jumlah pelayanan yang tidak dapat ditunda seperti Hemodialisis, persalinan, pelayanan thalassemia dan lain-lain proporsinya meningkat terhadap total kunjungan sehingga menyebabkan terjadinya perubahan pola casemix index di RS.

\section{Tantangan Piloting Global Budget}

Terdapat beberapa tantangan dalam pelaksanaan uji coba global budget di beberapa daerah yaitu:

1. Pandemi Covid-19 memberikan dampak signifikan terhadap kunjungan di rumah sakit sehingga sangat mempengaruhi selisih budget dengan realisasi klaimnya di tahun 2020. Terdapat situasi ketidakpastian yang diakibatkan oleh pandemic Covid-19. Diperkirakan dampak pandemi ini tidak akan selesai dalam waktu dekat sehingga mempengaruhi penghitungan global budget di tahun-tahun berikutnya

2. Fluktuasi jumlah peserta karena adanya kebijakan eksternal merupakan variabel 
yang berkontribusi terhadap selisih antara budget dan realisasi klaim.

3. Perubahan (penambahan atau penurunan) kapasitas RS termasuk perubahan tipe RS dalam tahun berjalan sangat mempengaruhi besarnya gap antara global budget dan realisasi klaim. Selisih ini tidak hanya terjadi pada RS yang bersangkutan namun juga pada RS lainnya karena adanya shifting pasien antar RS.

4. Perubahan kepemimpinan di RS mengharuskan adanya upaya sosialisasi yang terus menerus oleh KC BPJS.

5. Ketersediaan sistem informasi di RS yang sangat bervariasi berpengaruh terhadap kesiapan RS dalam menyiapkan data klaim yang dibutuhkan dalam penghitungan global budget. Terdapat beberapa rumah sakit yang akhirnya menggunakan data dari BPJS Kesehatan karena tidak memiliki data klaim secara utuh.

6. Pada tahun 2020 terdapat 2 RS di Kabupaten Tanah Datar yang telah mendapatkan dana global budget per termin. Tantangan yang dihadapi oleh BPJS Kesehatan adalah menyiapkan kebijakan dan sistem yang mengakomodir pemberian dana per termin serta memastikan ketersediaan anggaran pada periode tertentu sesuai dengan kesepakatan yang dibuat. Selain itu perlu dibuat sistem yang mempermudah proses penghitungan global budget dan monitoring-evaluasinya terhadap pemanfaatan pelayanan kesehatan dan realisasi Global Budget.

7. Pada tahun 2021, pemberian dana global budget per termin akan diberlakukan pada 30 RS. Terdapat RS yang saat ini mengalami krisis manajemen keuangan sehingga muncul diskusi penggunaan uang muka yang akan diberikan per termin guna menutupi defisit RS. Hal ini dikhawatirkan akan menimbulkan potensi penyalahgunaan dana dan pengurangan cakupan sehingga dirasa diperlukan mekanisme untuk memastikan kinerja keuangan rumah sakit.

\section{Kesimpulan dan Saran}

Sistem Pembayaran Mix-method global budget dapat digunakan sebagai alternatif pembayaran guna menjaga budget secara nasional namun perlu dikembangkan model untuk memprediksi jumlah kunjungan karena kepesertaan JKN yang masih fluktuatif sebelum Universal Health Coverage (UHC) dari sisi peserta tercapai. Pada kondisi normal, metodologi penghitungan global budget yang diterapkan cukup akurat untuk memprediksi kebutuhan pendanaan di RS. Selain itu penghitungan global budget di tingkat Kabupaten/Kota lebih bagus hasilnya dibandingkan dengan menghitung global budget langsung di tingkat RS karena mengakomodir shifting pasien dari RS yang satu ke RS yang lainnya karena perubahan kapasitas RS.

Untuk mengelola perubahan kapasitas di tahun berjalan sebaiknya di buat pengaturan rentang waktu perubahan kapasitas yang akan ditolerir oleh penghitungan Global Budget. Keterlibatan dan peran BPJS Kesehatan dan Dinas Kesehatan dalam perencanaan pelayanan Kesehatan di kabupaten/kota harus ditingkatkan agar terjadi sinkronisasi antara supply layanan dengan demand peserta JKN. Hal ini bisa ditempuh dengan penguatan koordinasi antar Lembaga, sehingga RS tidak berjalan sendiri dalam pengembangan layanannya. Melalui mekanisme ini maka efisiensi pelayanan kesehatan akan lebih mudah tercapai.

Global Budget tidak dapat berjalan "sendiri" namun perlu di implementasikan Bersama intervensi lain untuk mencapai tujuannya. (Penguatan FKTP, Indikator yang lain seperti readmisi, kasus rujukan, kasus outlier dan inlier dan lain lain). Penguatan FKTP sebagai gate keeper juga harus dilakukan secara paralel 
dengan implementasi global budget agar tujuan efisiensi dapat tercapai.

Mengingat adanya situasi ketidakpastian akibat pandemik Covid-19 maka Tahap Pertama Piloting Global Budget yang awalnya direncanakan berjalan selama 2 tahun sebaiknya diperpanjang. Pada pelaksanaan Tahap Pertama ini belum ada pembagian risiko atas lebih atau kurangnya realisasi klaim terhadap besaran global budget di RS pada tahun 2021. Pada tahap ini telah terjadi perubahan bisnis proses internal yaitu percepatan pengajuan klaim oleh rumah sakit ke BPJS Kesehatan dan analisa utilisasi berdasarkan CBG yang memantau casemix dan casemix index.

Untuk mengantisipasi perubahan jumlah peserta, kapasitas rumah sakit serta adanya pengaruh eksternal (kebijakan nasional) yang mempengaruhi jumlah kunjungan dan biaya pelayanan maka sebaiknya dilakukan update penghitungan global budget di tengah tahun. Dari hasil evaluasi piloting mix method INA-CBG dan global budget perlu disusun road map lebih detail untuk pelaksanaan Tahap 2 dan Tahap 3 . Beberapa negara menetapkan hard cap budget dimana RS tidak akan diberikan tambahan dana bila pelayanannya melampaui budget yang telah ditetapkan, namun tentunya didukung dengan finansial dan sistem yang mumpuni.

Selain itu perlu adanya penguatan FKTP dalam implementasi Global Budget. Dengan semakin kuatnya FKTP sebagai Gate Keeper maka tingkat rujukan ke RS dapat dikendalikan. Penguatan FKTP ini sangat memerlukan dukungan dari Pemda terutama Dinas Kesehatan yang membawahi Puskesmas. Upaya penguatan FKTP untuk menekan angka rujukan juga dilakukan oleh BPJS. Saat ini telah dilakukan beberapa kajian diantaranya adalah Layanan refraksi, telemedisin dan pelayanan gigi.

Memastikan supply dan distribusi Faskes terutama RS secara efektif dan efisien (RS, Jumlah TT, Layanan Kesehatan). Seperti diketahui bahwa ijin pendirian fasilitas Kesehatan baik rumah sakit maupun klinik berada di tangan Dinas Kesehatan. Dari pemetaan ketersediaan tempat tidur dan kapasitas rumah sakit diketahui bahwa banyak sekali RS memiliki BOR yang sangat rendah. Fenomena ini menggambarkan terjadinya over supply di beberapa kabupaten/kota dan di saat yang sama perijinan faskes yang baru terus berlangsung. Over supply akan menimbulkan inefisiensi tidak hanya di tingkat RS namun juga pada JKN.

Perencanaan Program Pelayanan Kesehatan yang berkesinambungan. Dengan keterlibatan Dinas Kesehatan pada proses kesepakatan GB maka Dinas Kesehatan memiliki informasi yang komprehensif tentang penyakit terbanyak di RS. Informasi ini akan sangat bermanfaat bagi Dinas Kesehatan dalam perencanaan program pelayanan ke depan.

Salah satu contoh terdapat kabupaten yang terlibat secara aktif pada proses penghitungan dan kesepakatan global budget. Dinas Kesehatan sangat responsif dengan membuat langkah tindak lanjut berupa koordinasi dengan semua RS serta pemenuhan kebutuhan pelayanan di tingkat kabupaten/kota.

BPJS Kesehatan Kantor Cabang menyediakan data klaim yang terjadi saat ini sehingga diketahui penyakit atau kasus apa saja yang dilayani oleh RS pada kabupaten/kota tersebut dan kasus apa saja yang dirujuk keluar kabupaten/kota padahal RS yang ada mampu menanganinya. Dengan adanya pertemuanpertemuan tersebut maka mulai diinisiasi langkah untuk menekan angka rujukan keluar kabupaten dan mengoptimalkan RS yang ada. Bila diperlukan rujukan ke RS tipe B maka akan dirujuk ke RS didalam wilayah kabupaten/kota dan bukan keluar kabupaten/kota tersebut. Setelah diketahui kasus apa saja yang selama ini dirujuk keluar kabupaten/kota, akan dipetakan RS mana yang ingin mengembangkan layanan guna menangkap potensi tersebut sehingga tidak 
semua RS akan menginvestasikan dananya pada layanan yang sama. Rumah sakit di dorong untuk memanfaatkan data klaim yang ada sebagai basis pengembangan layanan RS

\section{Daftar Pustaka}

Cots, F., Chiarello, P., Salvador, X., Castells, X., \& Quentin, W. (2011). DRG-based hospital payment: Intended and unintended consequences. In R. Busse, A. Geissler, W. Quentin, \& M. Wiley, Diagnosis-Related Groups in Europe Moving towards transparency, efficiency and quality in hospitals. New York: Mc Graw Hill.

Fattore, G., \& Torbica, A. (2006). Inpatient reimbursement system in Italy: How do tariffs relate to costs? Health Care Manage Sci.

Francis, Mertens, I., Closon, M.-C., \& Hofdijk, J. (2001). Casemix: Global Views, Local Action Evolution in Twenty Countries. Amsterdam: IOS Press.

García, J., Gomez, J., Hidalgo, L., \& Fernandez, J. (2004). Readmission rate as an indicator of hospital performance: The case of Spain. International Journal of Technology Assessment in Health Care

Langenbrunner, J. C., Cashin, C., \& O'Dougherty, S. (2009). How To M An Introduction to Provider Payment System. In , Designing and implementing health care provider payment system

McIntyre, D., \& Kutzin, J. (2016). Health

Financing Guidance No 1; Health

financing country diagnostic: a foundation for national strategy development . Geneva: World Health Organization

Mendez, C. M., Harrington, D. W., Christen, P., \& Spellberg, B. (2014). Impact of Hospital Variables on Case Mix Index as a Marker of Disease Severity. Population Health Management, Volume 17. doi:10.1089/pop.2013.0002

Murray, J. E. (n.d.).

Murray, J. E. (2017, March 14). The CDI buzz about CMI: What your facility metrics mean. Retrieved from Association of Clinical Documentation Integrity Specialist : https://acdis.org/articles/guestpost-cdi-buzz-about-cmi-what-yourfacility-metrics- mean

O’Dougherty, S., Cashin, C., Samyshkin, E., Ibraimova, A., Katsaga, A., Kutanov, E., . - Zues, O. (2009). Case Based Hospital Payment System. In J. C. Langenbrunner, C. Cashin, \& S. O'Dougherty (Eds.), In Designing and implementing health care provider payment system: How To Manuals. . Wahington DC.

OECD. (2013). MANAGING HOSPITAL VOLUMES GERMANY AND EXPERIENCES FROM OECD COUNTRIES.

Schreyogg, J., Stargardt, T., Tiemann, O., \& Busse, R. (2006). Methods to determine reimbursement rates for diagnosis related groups (DRG): A comparison of nine European countries. . Healt Care Manage Sci.

Vogl, M. (2012). Assessing DRG cost accounting with respect to resource allocation and tariff calculation: the case of Germany. Health Economics Review 